\title{
The Climate of the Borna Maggiore di Pugnetto Cave (Lanzo Valley, Western Italian Alps)
}

\author{
Luigi Motta, Michele Motta*
}

Department of Earth Sciences, Turin University, Italy

Copyright (C) 2015 Horizon Research Publishing All rights reserved.

\begin{abstract}
We have studied the internal climate of the Borna Maggiore di Pugnetto (Western Alps), starting from the survey of geological structure, of geomorphology and of vertical distance between cave floor and topographic surface. Then we studied the variations in temperature in the soil and in the air; the distribution of temperature and humidity in soil and air on four days that representing the four seasons. According the geomorphic data, the Borna is a through cave (hydro-geological tunnel). Three major heat sources regulate the thermal dynamics of the cave. In a branch enters water relatively warm, which is the main responsible for the distribution of temperature in this part of the cave. The entrance (at the opposite side of the cave) puts in communication the cave with the outer atmosphere, causing temperature changes, more and more attenuated inwards. Thermal imbalance between cave's ends probably causes the air circulation, which tends to homogenize the temperature of the air and soil, especially in the innermost part of the cave. The drip water is the third heat source: after the rains, causes sudden changes in temperature since October until June, after the starting of period of water surplus. The thermal dynamic of the cave makes almost constant temperatures, and divides the inner atmosphere in thermic zones, such as cold depressions, areas with constantly mild temperature, and traps to the warm air. This, combined with the constant temperature difference between air, walls and floor of the cave, creates many adjacent microhabitats. This factor, together at the proximity to glaciers in past, explains the great biodiversity of the cave.
\end{abstract}

Keywords Temperature, Humidity, Subterranean climate, Thermal dynamics, Cave zonation.

\section{The CaveLab Project and the Borna Maggiore di Pugnetto}

The interdisciplinary project CaveLab "From microclimate to climate change: Caves as laboratories for the study of the effects of temperature on ecosystems and biodiversity" was born in 2013 at the University of Turin, with a team composed of several members of the departments of Life Sciences and Biology of the Systems, Earth Sciences, General Physics, Plant Biology and Analytical Chemistry [10].

The central theme is the study of the influence of temperature on the dynamics of the subterranean ecosystems. We study about thirty of Piedmont caves. Somewhat contain cryophilic species, which maybe are arrived during the glaciations.

The project begins with the characterization of the cave environment. The next step takes into account the influence direct and indirect of factors such as availability of trophic resources, the human disturbance, the structure of the biocoenosis and the habitats, the ancient climate and extension of Quaternary glaciers (Fig. 1). We evaluate the influence of temperature on each part of the ecosystem, by means of direct measurements and statistical models. The ultimate goal of the project is: from a scientific point of view, improve knowledge of the impact on ecosystems of sudden variations (in time of the evolution of species) of climate such as the deglaciation, or in a future scenario, the global warming; from a practical point of view, give advice for the good management of the tourism inside caves containing sensitive species.

The Borna Maggiore di Pugnetto (1501 Pi/TO, 375551E $5014621 \mathrm{~N}, 820 \mathrm{~m}$ a.s.l.) is a well-known cave, which was intensively studied since very long time (e.g. [20-23,5,6,14,25,3].

The Pugnetto cave system is located in a lens made of carbonate-rich calcschist that are inside of insoluble rocks (gneiss, prasinite, serpentinite). The caves within calcschist are uncommon [6] and so the Pugnetto area is a unique karst landscape in a vast region of the Alps without other karstlands. Within of the calcschist, the fractures (i.e. joints, faults and schistosity planes) enlargement by dissolution together to processes of cave breakdown has created four caves: Borna Maggiore (= Main Cave in Piedmontese), Tana del Lupo or Grotta Inferiore di Pugnetto (1502 Pi/TO), Creusa d'le Tampe or Grotta Superiore di Pugnetto (1503 Pi/TO), Tana della Volpe (1504 Pi/TO). 


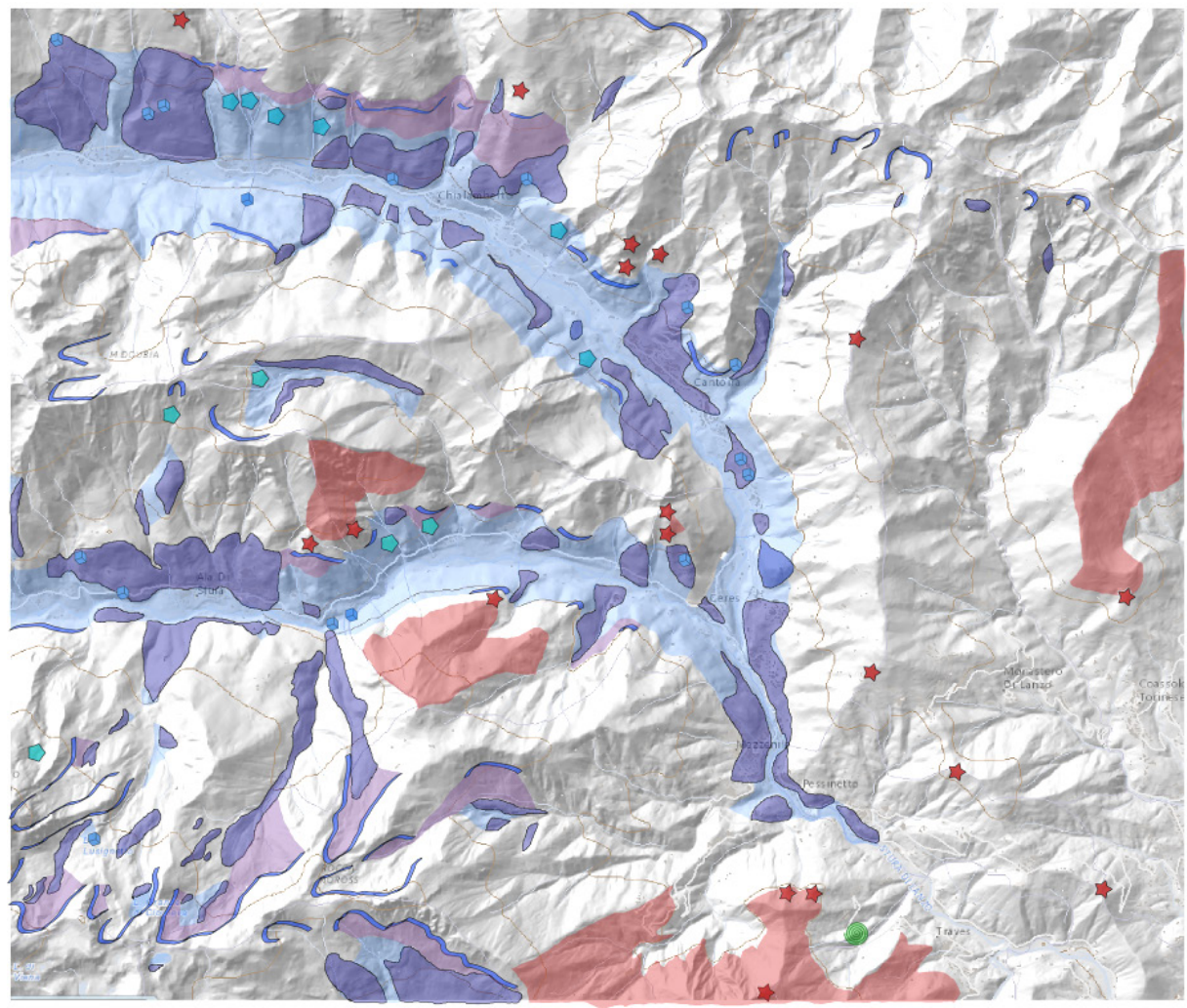

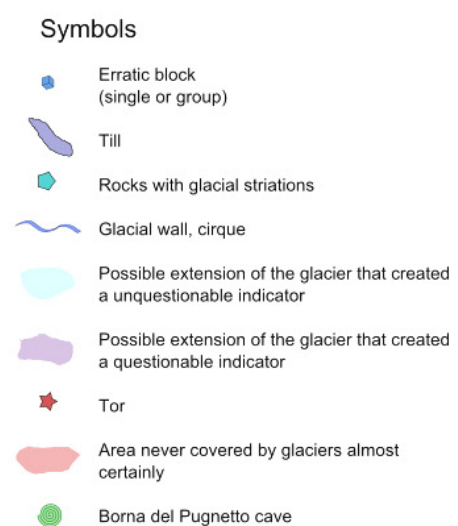

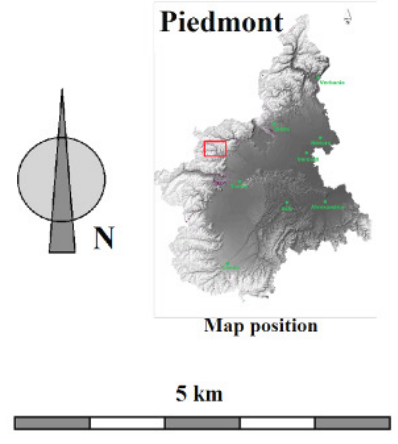

Figure 1. Geomorphic indicators of glacial passage (erratic blocks, glacial deposits, rocks with glacial striations, glacial walls, cirques) and indicators of lack of glacial processes (tors) in Lanzo Valleys. Cartography from [27], processing in [19].

The Pugnetto area represents an important spot of hypogean biodiversity in the Western Italian Alps. It hosts several natural caves classified by law (European Habitat Directive 43/92, S.C.I. IT 1110048) as "Caves not open to the public" (H 8310), because these caves are exploited as a winter shelter by several species of bats, such as Myotis emarginatus, M. myotis, Rhinolophus ferrumequinum, $R$. hipposideros [24]. The Pugnetto caves host several important endemic invertebrates also. Among these, it is worth to mention Dellabeffaella roccai (Insecta, Coleoptera, Cholevidae, Leptodirinae), which is described as the most specialized Leptodirinae in Piedmont [1,13,26], Sphodropsis ghilianii ghilianii (Insecta, Coleoptera, Carabidae, Sphodrini), Alpioniscus feneriensis caprae (Crustacea, Isopoda, Trichonischidae), Dolichopoda ligustica septentrionalis (Insecta, Orthoptera, Rhaphidophoridae) and Troglohyphantes bornensis (Arachnida, Linyphiidae), a cryophilic steno-endemic spider $[8,9]$.

Such biodiversity likely reflects the glacial history of the site. Never during the Pleistocene has the ice covered the cave (Fig. 2), but the glacial snout stood $1 \mathrm{~km}$ away from the cave $[16,17,19]$. For this reason the site should act as a glacial refuge for several cryophilic species [4].

\section{Objectives}

The objective of this paper is to show the thermal dynamics of Borna Maggiore, an alpine cave considered an excellent example of high biodiversity (S.C.I., i.e. Site of Community Importance). Besides, the collected data will useful, together with the ones of similar investigations in other caves, for the generalization of the results.

\section{Geomorphologic data of the Borna Maggiore}

In order to know the cave geomorphology better, we have made a survey of the sets of joints and faults, and we have measured the vertical distance between floor of cave and surface of hill (Fig. 3). Truc d'le Tampe, the hill that contains the cave, has a true karst area, with sinkholes and a doline. In spite of this, inside of the cave, karstic forms of corrosion virtually do not exist. The Borna Maggiore is a joint-plane cave developed at the intersection of several sets of fractures. They are: fault planes $\mathrm{F} 1$ (from $336^{\circ} / 71^{\circ}$ to $310^{\circ} / 76^{\circ}$ ) that separate rocks with bedding joints $\mathrm{S} 1\left(60^{\circ}-84^{\circ} / 33^{\circ}-60^{\circ}\right)$ from other with S1 $165^{\circ} / 59^{\circ}$; joint planes $\mathrm{J} 10^{\circ} / 80^{\circ}$; J2 $\left(124^{\circ}-130^{\circ} / 50^{\circ}\right)$. The cave is almost horizontal, because the soluble rocks (calcschist and marble) that host the galleries rest above a confining unit made of permeable, but non-cavernous phyllite. The cave has four parts (Fig. 4).

1. Madonna Branch and Main Branch from entrance as far as the fork between Madonna Branch and Fountain Branch: they are dry and horizontal galleries with some chambers created by fall of rock masses from ceiling. Prior to removal, by the mineral collectors, were abundant plates of large crystals of calcite grown underwater and opal concretions [3]. Therefore, the cave development is probably due to a water stream that has enlarged a passage close to the water table. 
During some periods the corrosion process (in phreatic conditions) has enlarged the galleries; otherwise in the cave the conditions were suitable for a calcite and opal precipitation. Today, this part of the cave is always in vadose zone. The water is dripping in main gallery for its entire length (sometime at least), but the dripstone are little developed (even before the devastation because of collectors). This suggests that the condition vadose of gallery is quite recent. At the end, Madonna Branch is very close to the topographic surface.

2. Both the Fountain Branch, with its perennial source, and the parallel short branch, with its intermittent waterfall, are typical galleries of back flooding, with the morphological features of epiphreatic condition (ceiling channels...). The current aspect is also the result of successive process of cave breakdown.
3. The water flowing in Fountain Branch after a few meters sinks in Lower Branch, that is parallel and below the Fountain Branch. This branch becomes after a few meters virtually impassable [20,21]. The Lower Branch is an epiphreatic passage that links the bottom of Fountain Branch to the active cave. The underground stream of Lower Branch flows exactly below the floor of Fountain Branch, and probably continues, going near to the lowest part of the Borna (Left Galleries). The corrasion is the main process of erosion in Lower Branch, because the floor is made of calcareous phyllite that is little soluble and very soft.

4.Left Galleries are the lowest sector, underneath the entrance gallery. The largest chamber, floored by collapse debris, once hosted a cave lake [20,21], probably linked to the water table.

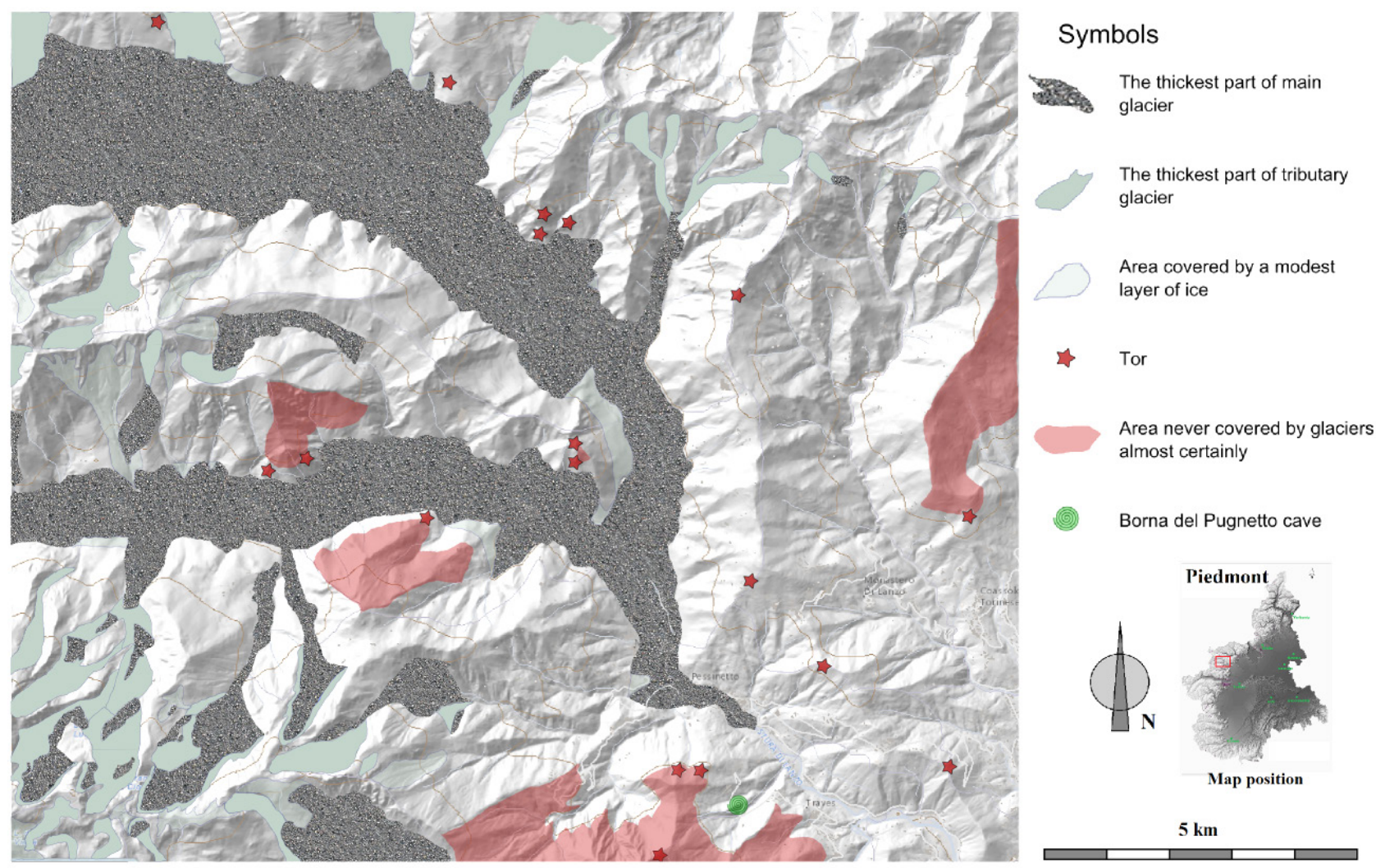

Figure 2. Areas surely covered by glacier during the Pleistocene in the Lanzo Valleys, and areas certainly never covered by a glacier, according to the morphological indicators. Cartography from [27], processing in [19]. 


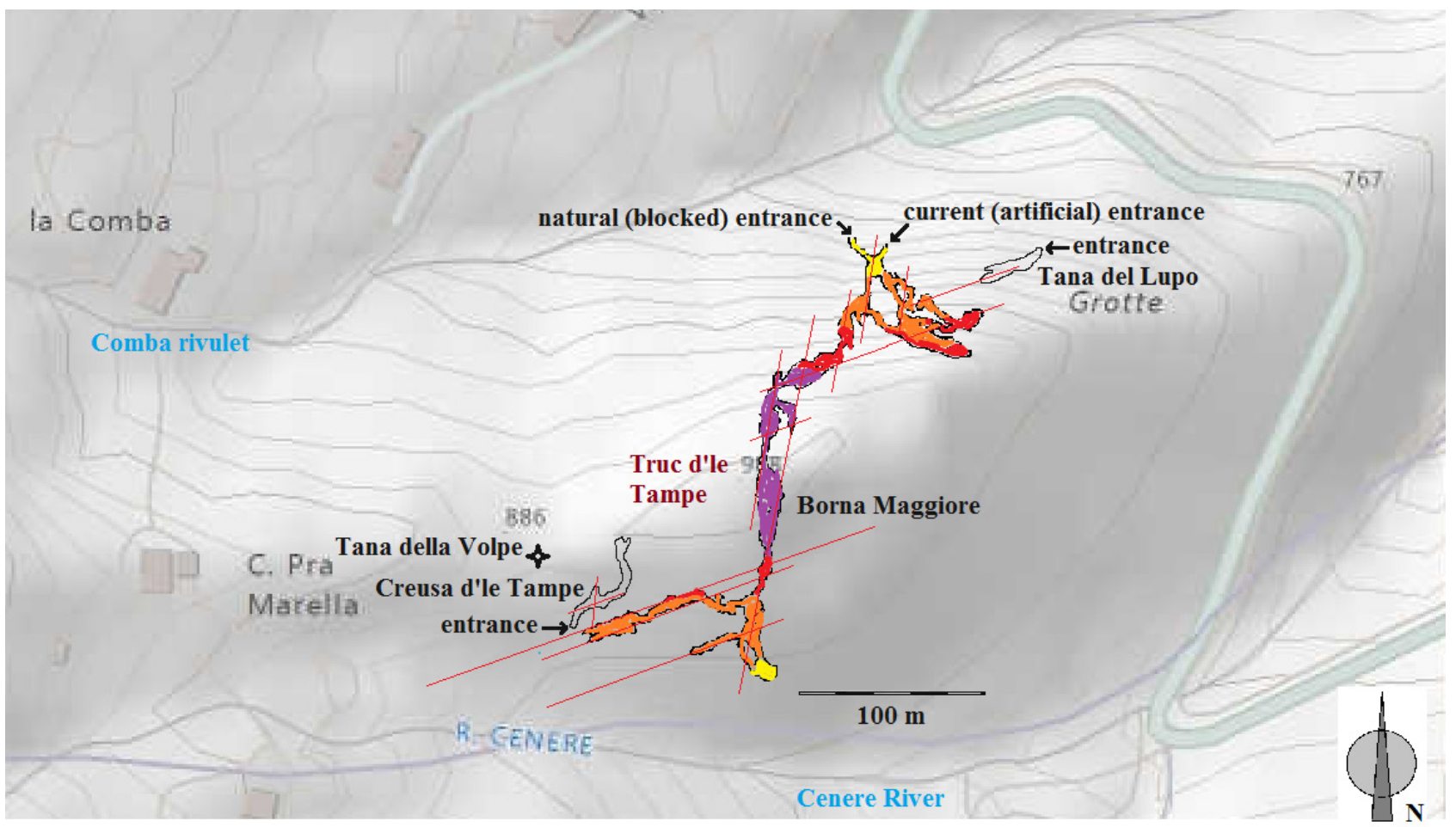

Figure 3. Position of the caves and major sets of joints and faults (red lines). The colors represent the vertical distance between the floor of Borna Maggiore and the surface of hill. Yellow: 0-20 m; orange: 20-40 m; red: 40-60 m; violet: 60-80 m.

\section{Discussion of the geomorphologic data}

The proximity between cave ceiling and surface of hill, the independence of the path from the external morphology (Fig. 3 ) and the temperature of the fountain rather constant (annual excursions of temperature: $4.6^{\circ} \mathrm{C}$; average: $10.1^{\circ} \mathrm{C}$ ) are evidences that the Borna is a through cave (i.e., a hydro-geological tunnel). The autogenic drainage is secondary: only the small closed basin at $886 \mathrm{~m}$ a.s.l. (Fig. 3) is an actual karst seep, with a true sinkhole (Tana della Volpe, $883 \mathrm{~m}$ a.s.1.).

Probably, the main reason of the genesis of Pugnetto caves is the slight difference in height between Cenere Valley and Comba, a parallel and tributary valley (near Pugnetto). The rocks of the watershed have secondary and tertiary porosity. Therefore, a karst aquifer carries a canal seepage loss of the Cenere River to Comba Rivulet, going at shallow depth under Truc d'le Tampe, the watershed that separates the two valleys. The losing stream is the part of Cenere River above $880 \mathrm{~m}$ a.s.l., which flows parallel at the major set of joints of Fountain Branch. The yield of the cave stream is usually $<1$ $1 / \mathrm{s}$, i.e. a simple canal seepage loss. Nowadays the Borna Maggiore not contains allochtonous pebbles that can come from Cenere River (the rocks coming from upstream are easy to recognize, because they are only serpentinite and gneiss, without calcschist). Therefore, never a watercourse arrived directly in the cave from outside. This explains why, although a lot of collectors have dug everywhere in the cave, they have never found fossils. The absence of large Mammals and old artifacts probably derives from the absence or obstruction of entrance in the past, and (more recently) from the absence of karst shafts that act as natural traps.

Once, probably the main stream flowed through the Madonna Branch, which ends at less of 20 meters to hill surface. When this branch was active, the cave had a hump in half (with a narrow that shows still today the siphon feature) and probably the water, through the Left Galleries, came in those times to Tana del Lupo (at $70 \mathrm{~m}$ from the Borna entrance, $7 \mathrm{~m}$ below), which was the outflow cave. The natural entrance of Borna Maggiore (a narrow tunnel blocked for safety; the current entrance is artificial) is a secondary passage of the autogenic drainage.

40 meters over the Borna, the Creusa d'le Tampe is very close (horizontal distance of about ten meters), and it follows the same fracture set of Fountain Branch. This cave may be all that remains of a similar and oldest hydro-geological tunnel, or a cave system of the autogenic drainage, together to the Tana della Volpe.

Karst breccia made of marble and calcschist fragments, with large interstices and voids, partially covers the lower part of slopes of Truc d'le Tampe. Soil with a thick epipedon covers in turn the breccia. Reference [11] has described ecologically this interstice-like habitat as Milieu Souterrain Superficiel or Underground Superficial Compartment (MSS), and [12] has reported this habitat also in the karst breccia.

\section{Climatic data collection}

To know the dynamics of thermic exchanges, it is obvious that we need first to know the temperature of the cave and its variations, both temporal as spatial. In this paper, in 
particular, we will present four data groups.

- Data of ground temperature. The sensors are seven I-buttons Hygrochron - DS1923 that were into the shallow ground, relatively far from the walls and very far from the active watercourse (Fig. 4; G1 is at the cave entrance, in twilight zone). The sensors have a nominal accuracy of $0.0625^{\circ} \mathrm{C}$; they have measured the temperature every three hours. The period of analyses is from 27 May 2012 up to 6 February 2013 (Fig. 5). The Hygrochron have also a humidity probe, but almost all of these measures have had a fails because of inappropriate working conditions (very long period of high humidity). Therefore, we believe unreliable the few data obtained.

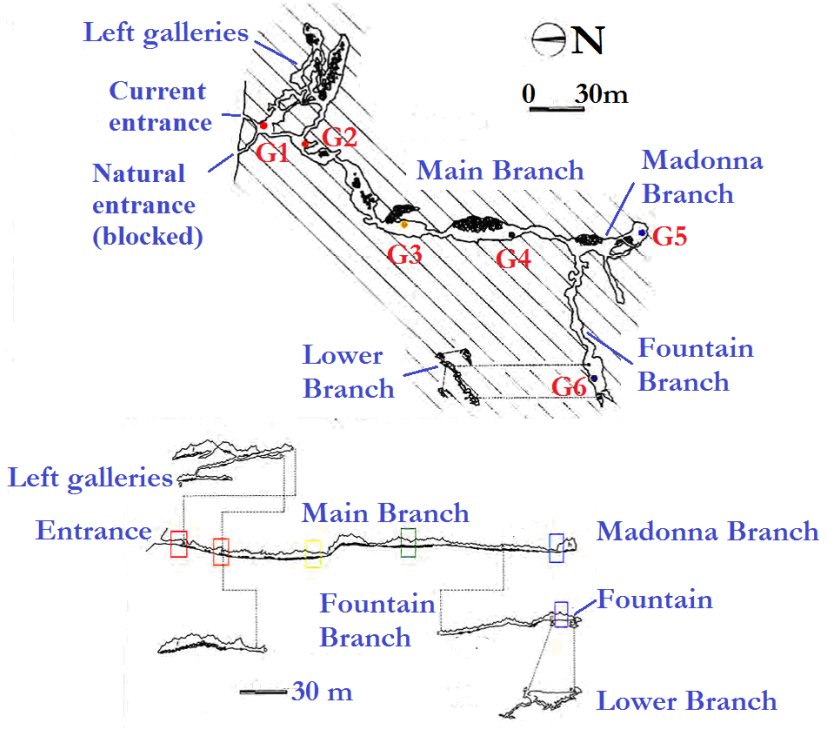

Figure 4. I-buttons arrangement.

- Seasonal data (31 July 2013, 30 October 2013, 28 January 2014, 8 May 2014) of temperature and relative humidity. The measures are made by a Delta $\mathrm{Ohm}$ thermohygrometer HD9216 through the longitudinal section of the cave, with an interval of $10 \mathrm{~m}$ (interval that seems appropriate for the temperature variability within this cave), in the lowest point of the floor within the ground (Pt100 TP9AP probe placed at $60 \mathrm{~mm}$ depth), in the air (air probe HD9216S at $1.5 \mathrm{~m}$ above ground level), in dripping water (TP9A probe) [2]. The temperature precision is $\pm 0.1^{\circ} \mathrm{C}$ plus linearization error $\left(0.04^{\circ} \mathrm{C}\right) \pm 1$ digit. The humidity precision for the complete instrument is $\pm 2 \%$ in the range $5 \% . . .90 \%,+4 \%$ $/-2 \%$ in the range $90 \% . . .98 \%$. A long support has kept the air probes away from the operator some meters, so as to avoid the risk that the human body changes the measures.

- The air temperature measured in cross sections, according to a rectangular mesh grid of $0.5 \mathrm{~m}$, with an air probe HD9216S.

Moisture distribution within many rock surfaces. The measure instrument is a dielectric moisture indicator T650
Trotec (penetration depth $20-40 \mathrm{~mm}$ ), and its aim is to recognize the saturation state of the rock (dry / damp / wet).
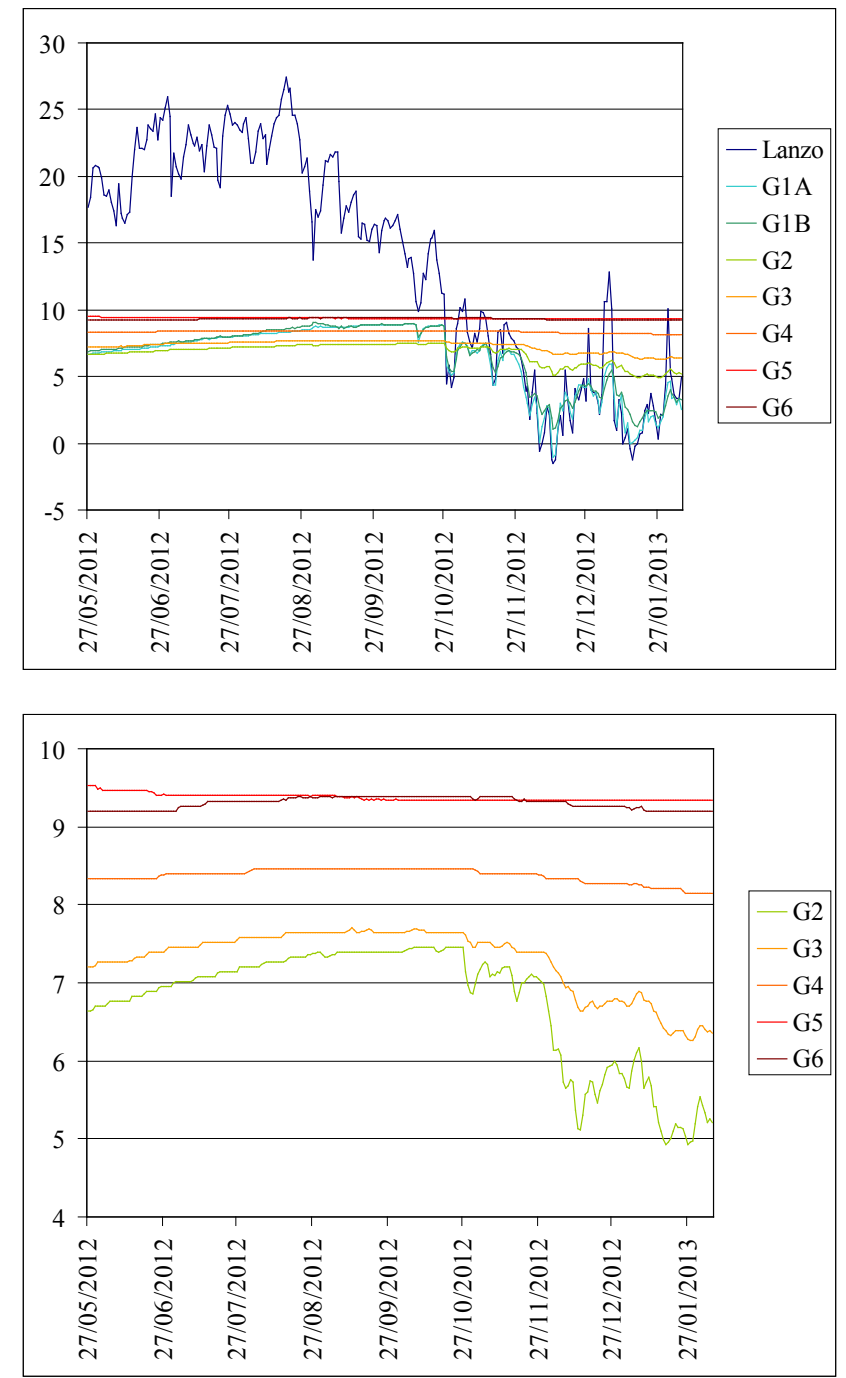

Figure 5. Temperature $\left({ }^{\circ} \mathrm{C}\right)$ measured by I-buttons, respectively at 3 (G1 A and B), 30, 90, 150, 230, $350 \mathrm{~m}$ from current entrance, and temperatures recorded by weather station ARPA of Lanzo. The second graph reports only the data recorded in the innermost part of the cave for a better understanding.

\section{The data collected by the I-buttons}

First, we have done the validation of the data and the aggregation at monthly level. In [18] we have published the analysis of the I-buttons data together to the data of the other caves studied by CaveLab. Tab. 1 reports the data of two I-buttons placed within the Borna Maggiore.

To estimate the annual data despite the short observation period, we use only the monthly mean temperatures of January 2013 and July 2012 with their standard deviation (both calculated on the basis of daily data), and the average of the thermic daily excursions recorded during two months already mentioned (tab. 2). The table shows as well:

- the average of the monthly values already mentioned; given the relative stability of the hypogeous thermic conditions, it can be an estimate of the average annual 
temperature;

- the difference in value; it does not indicate the annual thermic excursion (indeed, January and July are almost never, the coldest month and the warmest, see Fig. 1 of [18]), but it gives an idea of the difference between the seasons anyway.

Table 1. January 2013 temperature parameters, in ${ }^{\circ} \mathrm{C}$.

\begin{tabular}{|c|c|c|c|}
\hline $\begin{array}{c}\text { Distance from } \\
\text { entrance }\end{array}$ & Mean & $\begin{array}{c}\text { Monthly } \\
\text { excursion }\end{array}$ & $\begin{array}{c}\text { Daily excursion } \\
\text { (average) }\end{array}$ \\
\hline $3 \mathrm{~m}$ & 2.38 & 1.69 & 1.50 \\
\hline $230 \mathrm{~m}$ & 9.34 & 0.00 & 0.00 \\
\hline
\end{tabular}

To determine more accurately the position of the maximum and the minimum of the thermic curve and have a better estimate of the average and the annual thermic excursion, we calculated with the method of least squares the equalization of the thermic curve formed by 3-hours data with the sine function (1):

$\mathrm{T}=\mathrm{T}_{\mathrm{m}}+\mathrm{e}_{\mathrm{a}} \sin \left[2 \pi\left(\mathrm{t}-\mathrm{t}_{0}-\varphi_{\mathrm{a}}\right) / 365.2422\right] / 2+\mathrm{e}_{\mathrm{d}} \sin [2 \pi(\mathrm{t}-$

$$
\left.\left.0.25-\varphi_{\mathrm{d}}\right) / 24\right] / 2
$$

where $\mathrm{T}$ is the temperature laid down in time $\mathrm{t}$ (expressed in average of days since midnight 0.00 from 01.01.1900; the $t_{0}$
$=40988.6347 \underline{2}$ value corresponds to the spring equinox of 2012).

We thus obtain the values of:

$\mathrm{T}_{\mathrm{m}}$, estimate of average temperature $\left({ }^{\circ} \mathrm{C}\right)$,

$\mathrm{e}_{\mathrm{a}}$, estimate of the annual excursion $\left({ }^{\circ} \mathrm{C}\right)$,

$\mathrm{e}_{\mathrm{d}}$, estimate of the daily excursion $\left({ }^{\circ} \mathrm{C}\right)$,

$\varphi_{\mathrm{a}}$, estimate of the average of time (in days) since summer solstice until the moment when the thermic curve reaches the maximum value, and of time since winter solstice until the moment where the thermic curve reaches the minimum value. In other words, this parameter indicates the "phase delay" of the position of the maxima and minima of the sine curve of equalization of the thermic curve compared to the solstices.

$\varphi_{\mathrm{d}}$, estimate of the average of time (in hours) since midday until the moment when the thermic curve reaches the maximum value, and of time since midnight until the moment when the thermic curve reaches the minimum value.

Table 3 shows the parameters obtained from (1).

The daily excursions that are estimated by this technique are systematically lower than those calculated by an average measured, because the sinusoidal curve no approximates exactly the curve derived from the daily data.

Table 2. Values $\left({ }^{\circ} \mathrm{C}\right)$ of July 2012 and January 2013. Annual average estimated by January and July values mediated.

\begin{tabular}{|c|c|c|c|c|c|c|c|c|c|}
\hline \multirow{2}{*}{ I-button } & \multirow{2}{*}{ Distance from entrance } & \multicolumn{2}{|c|}{ Mean } & \multirow{2}{*}{ Difference } & \multirow{2}{*}{ Annual mean } & \multicolumn{2}{|c|}{ Standard deviation } & \multicolumn{2}{c|}{ Daily excursion } \\
\cline { 7 - 11 } & & January & July & & & January & July & January & July \\
\hline G1A & $3 \mathrm{~m}$ & 2.38 & 7.76 & 5.38 & 5.07 & 1.69 & 0.20 & 1.50 & 0.06 \\
\hline G1B & $3 \mathrm{~m}$ & 2.95 & 7.82 & 4.87 & 5.38 & 1.13 & 0.16 & 0.41 & 0.05 \\
\hline G2 & $30 \mathrm{~m}$ & 5.40 & 7.09 & 1.69 & 6.25 & 0.39 & 0.06 & 0.14 & 0.01 \\
\hline G3 & $90 \mathrm{~m}$ & 6.54 & 7.50 & 0.96 & 7.02 & 0.21 & 0.04 & 0.03 & 0.00 \\
\hline G4 & $150 \mathrm{~m}$ & 8.21 & 8.40 & 0.19 & 8.30 & 0.04 & 0.00 & 0.02 & 0.00 \\
\hline G5 & $230 \mathrm{~m}$ & 9.34 & 9.40 & 0.06 & 9.37 & 0.00 & 0.00 & 0.00 & 0.00 \\
\hline G6 & $350 \mathrm{~m}$ & 9.21 & 9.29 & 0.08 & 9.25 & 0.02 & 0.04 & 0.01 & 0.01 \\
\hline
\end{tabular}

Table 3. Values of $\mathrm{T}_{\mathrm{m}}, \mathrm{e}_{\mathrm{a}}, \mathrm{e}_{\mathrm{d}}\left({ }^{\circ} \mathrm{C}\right), \varphi_{\mathrm{a}}$ (days), $\varphi_{\mathrm{d}}$ (hours).

\begin{tabular}{|c|c|c|c|c|c|c|}
\hline I-button & $\begin{array}{c}\text { Distance } \\
\text { from current } \\
\text { entrance }\end{array}$ & $\mathrm{T}_{\mathrm{m}}$ & $\mathrm{e}_{\mathrm{a}}$ & $\varphi_{\mathrm{a}}$ & $\mathrm{e}_{\mathrm{d}}$ & $\varphi_{\mathrm{d}}$ \\
\hline $\mathrm{G} 1 \mathrm{~A}$ & $3 \mathrm{~m}$ & $7.89^{\circ}$ & $2.36^{\circ}$ & $129.6 \mathrm{~d}$ & $0.014^{\circ}$ & $20.5 \mathrm{~h}$ \\
\hline $\mathrm{G} 1 \mathrm{~B}$ & $3 \mathrm{~m}$ & $7.79^{\circ}$ & $2.38^{\circ}$ & $116.1 \mathrm{~d}$ & $0.025^{\circ}$ & $19.3 \mathrm{~h}$ \\
\hline $\mathrm{G} 2$ & $30 \mathrm{~m}$ & $6.98^{\circ}$ & $0.91^{\circ}$ & $105.8 \mathrm{~d}$ & $0.002^{\circ}$ & $9.8 \mathrm{~h}$ \\
\hline $\mathrm{G} 3$ & $90 \mathrm{~m}$ & $7.39^{\circ}$ & $0.57^{\circ}$ & $98.3 \mathrm{~d}$ & $0.004^{\circ}$ & $12.2 \mathrm{~h}$ \\
\hline $\mathrm{G} 4$ & $150 \mathrm{~m}$ & $8.31^{\circ}$ & $0.33^{\circ}$ & $82.4 \mathrm{~d}$ & $0.002^{\circ}$ & $26.5 \mathrm{~h}$ \\
\hline $\mathrm{G} 5$ & $230 \mathrm{~m}$ & $9.39^{\circ}$ & $0.12^{\circ}$ & $339.5 \mathrm{~d}$ & $0.001^{\circ}$ & $26.7 \mathrm{~h}$ \\
\hline $\mathrm{G} 6$ & $350 \mathrm{~m}$ & $9.25^{\circ}$ & $0.28^{\circ}$ & $103.5 \mathrm{~d}$ & $0.001^{\circ}$ & $24.0 \mathrm{~h}$ \\
\hline
\end{tabular}




\section{Discussion of the data collected by the I-buttons}

Reference [18] have proposed a subdivision of the caves studied by CaveLab (in Western Italian Alps) in four groups, on the basis of their thermic condition inside (tab. 4).

Table 4. Groups of thermic conditions of the caves.

\begin{tabular}{|c|c|c|c|}
\hline Group & Averages & Daily excursions & $\begin{array}{c}\text { Annual } \\
\text { excursions }\end{array}$ \\
\hline A & $8.5-10.5^{\circ} \mathrm{C}$ & $\begin{array}{c}\text { Very weak or } \\
\text { absent } \\
\left(<0.05^{\circ} \mathrm{C}\right)\end{array}$ & $\begin{array}{c}\text { Very weak } \\
\left(<0.6^{\circ} \mathrm{C}\right)\end{array}$ \\
\hline B & $6-9^{\circ} \mathrm{C}$ & $\begin{array}{c}\text { Very weak } \\
\left(0.02-0.10^{\circ} \mathrm{C}\right)\end{array}$ & $\begin{array}{c}\text { Weak } \\
\left(2-5^{\circ} \mathrm{C}\right)\end{array}$ \\
\hline $\mathrm{C}$ & $7.5-10.5^{\circ} \mathrm{C}$ & $\begin{array}{c}\text { Variable } \\
\left(0.20-1.00^{\circ} \mathrm{C}\right)\end{array}$ & $\begin{array}{c}\text { Relatively high } \\
\left(5-13^{\circ} \mathrm{C}\right)\end{array}$ \\
\hline $\mathrm{D}$ & $\begin{array}{c}3-8^{\circ} \mathrm{C} \\
\mathrm{T}<0{ }^{\circ} \mathrm{C} \text { in } \\
\text { January }\end{array}$ & $\begin{array}{c}\text { Moderate } \\
\left(0.05-0.35^{\circ} \mathrm{C}\right)\end{array}$ & $\begin{array}{c}\text { Relatively high } \\
\left(5-13^{\circ} \mathrm{C}\right)\end{array}$ \\
\hline
\end{tabular}

According to this classification, Borna Maggiore inside is in the Group A: the thermic conditions are almost stable over time, on a daily scale (excursions $<0.05^{\circ} \mathrm{C}$ ), as on an annual scale (excursions $<0.6^{\circ} \mathrm{C}$ ). The variable-temperature zone (up to $30 \mathrm{~m}$ from entrance) is in the group B. So, the whole Borna Maggiore is an insulated environment where a temperature change, even at a level over the year, occurs much attenuated and with great delay.

The daily excursions are very low already at the entrance and below the nominal accuracy of the probes at a depth of 30 meters (July) and $90 \mathrm{~m}$ (January; tab. 1 and 2).

The temperature oscillation in the course of the month is linked to weather changes on the outside, and is much low in hypogeal environment (Fig. 6). The evidence is the relatively low standard deviation of the data at monthly scale (tab. 2).
The causes that reduce this variability are almost the same of those that depress the daily excursions: this explains the good linear correlation between the two variables (according to Fig. 2 of [18]).

Inside, the Borna Maggiore has higher daily temperature in July than in January, while the same cave at the entrance has the opposite phenomenon. This phenomenon is not simply a consequence of variability in thermic conditions: the standard deviation of the data is higher in January than in July, although in July the daily excursion is higher than in January.

The equation (1) well portrays the annual thermic oscillations. Only in autumn, and only in the variable-temperature zone (G1A, G1B, G2 and G3 sensors) during some periods the temperatures are quite colder of the temperatures equalized by (1). In other words, during autumn, the temperature curve within the cave near the entrance evidences many sudden lowering (Fig. 5 and 6). This can be explained by variations of the flux of air coming from the outside (see paragraph of discussion of a hypothesis of thermic dynamics), and/or with variations induced by greater or lesser dripping resulting from the precipitations, which increase the deep percolation.

The water budget estimated for the soil on the hill over the cave (Fig. 7) indicates that in autumn the rainwater overcomes the groundwater storage; therefore during or immediately after the rains, much more water infiltrates and drips than in previous months. In winter, this effect should decrease when the soil freeze and becomes waterproof; in spring, as a rule, the water temperature is quite similar to inner temperature of the cave.

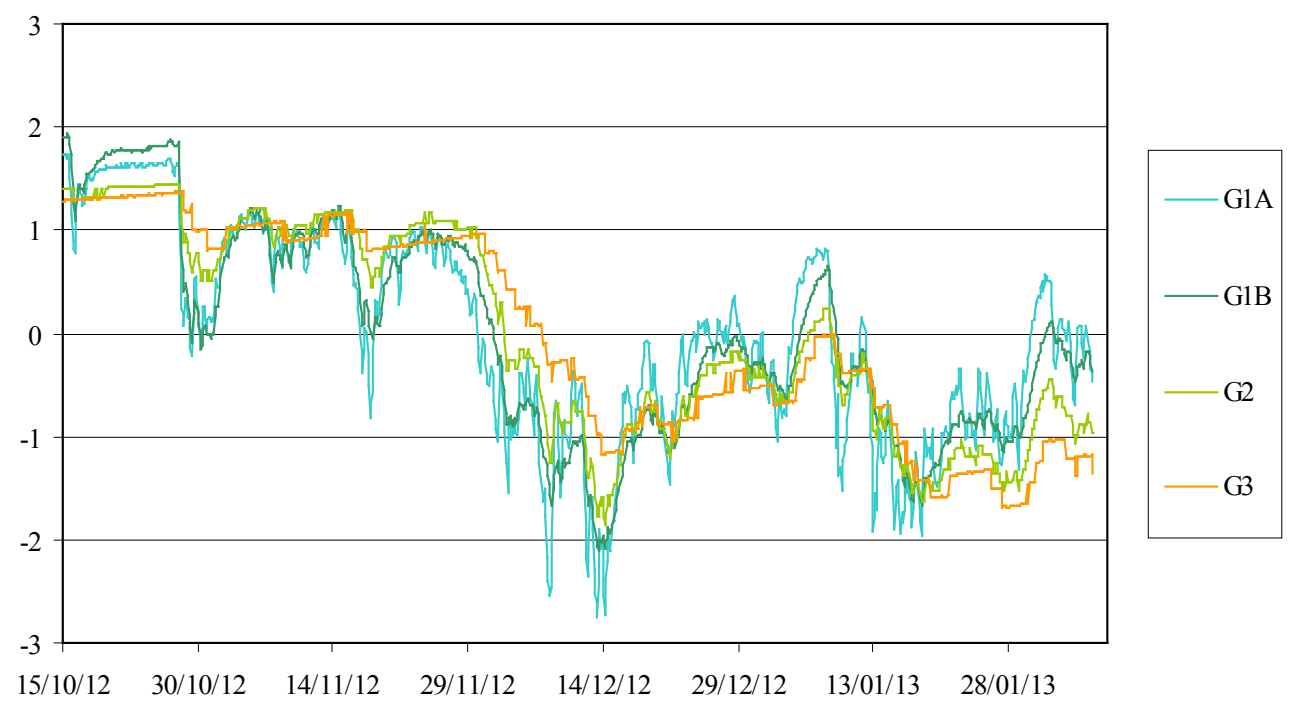

Figure 6. The comparison of standardized data $x^{\prime}=(x-\bar{x}) / \sigma$ recorded near to the entrance $(\mathrm{G} 1)$ and more inside (G2, G3), evidences a oscillation more and more low toward the inside. 


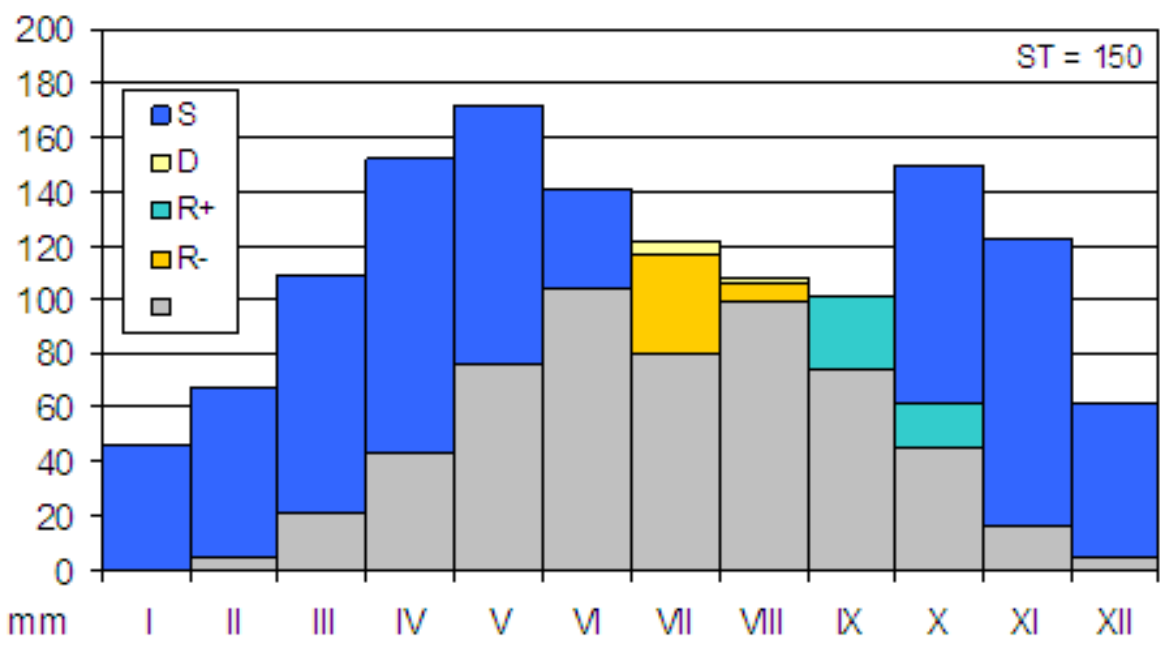

Figure 7. Thornthwaite diagram obtained by data of ARPA Piemonte, weather station of Lanzo (about 6 km from Borna Maggiore), corrected for the difference in altitude. The deep blue indicates water surplus, the pale yellow indicates deficit.

\section{The data collected in the four seasons}

Fig. 8 reports the map of temperature and humidity values, collected in the survey done along the longitudinal section.

Sometimes ceilings are dry, but commonly are wet. The dripping from ceiling, being abundant and in sharp rising after periods of rain, suggests that infiltration water is more than that of condensation. Besides, all the measurements of the internal water contents in the dripping ceilings have pointed out that the rock has the same wet inside. The temperature of this water has always turned out colder than the temperature of surrounding air (Fig. 8). We can reasonably think that this is mainly due to a low starting temperature of the infiltration water.

\section{Discussion of data collected in the four seasons}

On the basis of air temperature and relative humidity, we have calculated the values of absolute humidity (Fig. 9). No part of the cave is exactly dry or moist throughout the year as the rest of the cave. During the winter, because of the cold, the cave dries considerably near to the entrance, and the decrease of humidity is remarkable along the whole Main Branch. In spring, the first 60 meters from the entrance are still quite dry (see Fig. 9, May). In the autumn, however, the distribution of the absolute humidity is remarkably homogeneous. Within the Fountain Branch the absolute humidity remains constant and high year-round, due to the rather constant flux of liquid water. Within Madonna Branch the absolute humidity is like to the Fountain Branch but with even higher values during summer, for the warmest air.

The distribution of air temperature (Fig. 8) evidences clearly that an air circulation tends to homogenize the temperature. Some depressions of the cave, however, remain "cold holes" [2]: the main gallery to $40-120 \mathrm{~m}$ from the entrance and the galleries on the left, especially in winter. On the contrary, evidently the last chamber of Madonna Branch is a trap for the warm, humid air: in fact, both temperature and absolute humidity have high values respect to the soil temperature.

The relative humidity is extremely variable. Often the air is saturated with moisture inside of Fountain Branch (the branch with the water stream), but elsewhere, including the inner parts of the cave, it is normally very below the $100 \%$, even when drip abounds (in spring) and in spite of the bottom and walls of the cave are normally wet. In spring, the season of maximum uniformity of temperature (i.e. maximum of air circulation), the relative humidity is very variable in the very same branch, perhaps depending by condensation/evaporation phenomena caused by passage of air through alternation of chamber and narrow.

The distribution of ground temperature (Fig. 8) shows two areas of temperature variation:

- the first 140 meters from the entrance, where the temperature gradients suggest that the temperature variations are probably linked to the penetration of outer air, or are linked to temperature or to quantity of dripping water;

- Fountain Branch, where the change in temperature follows the variation of the temperature of the spring water, and evidently derives from it.

In the rest of the cave the temperature varies very little, also within Madonna Branch, which is located at a distance from the surface comparable to that of the cave zone with seasonal variations in temperature. This proves that the dripping undoes the effect of the air circulation (the air temperature ranges, albeit weakly, with the seasons) on soil temperature. In other words, despite the presence of a circulation of air, the effect of heat carried by the dripping water is preponderant when compared to air, starting from $140 \mathrm{~m}$ from the entrance. The result is normally a cooling of the floor, because the water of oozing is $0.6^{\circ} \mathrm{C}$ colder respect to air (average of 44 measures in the four seasons). 


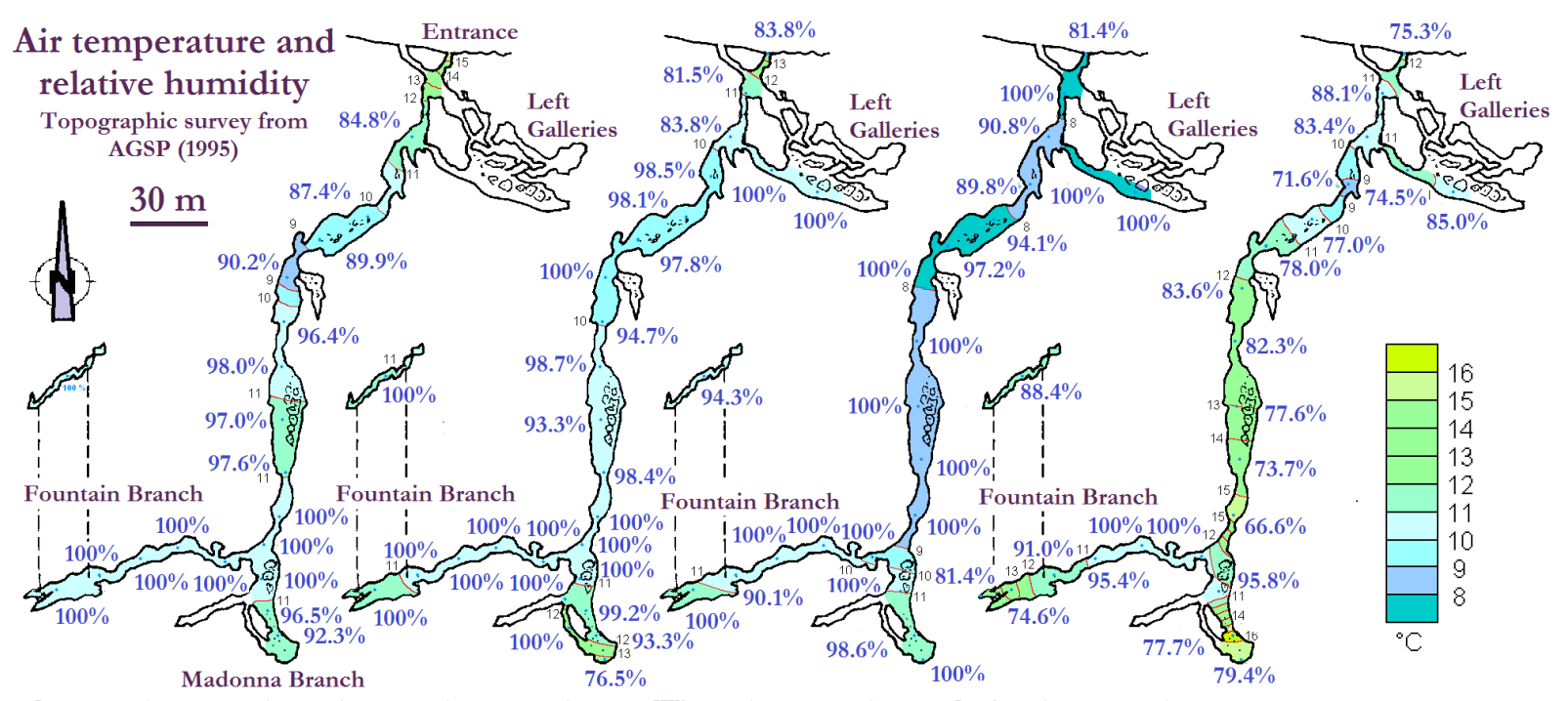

Summer (31.07.2013) Autumn (30.10.2013) Winter (28.01.2014) Spring (08.05.2014)

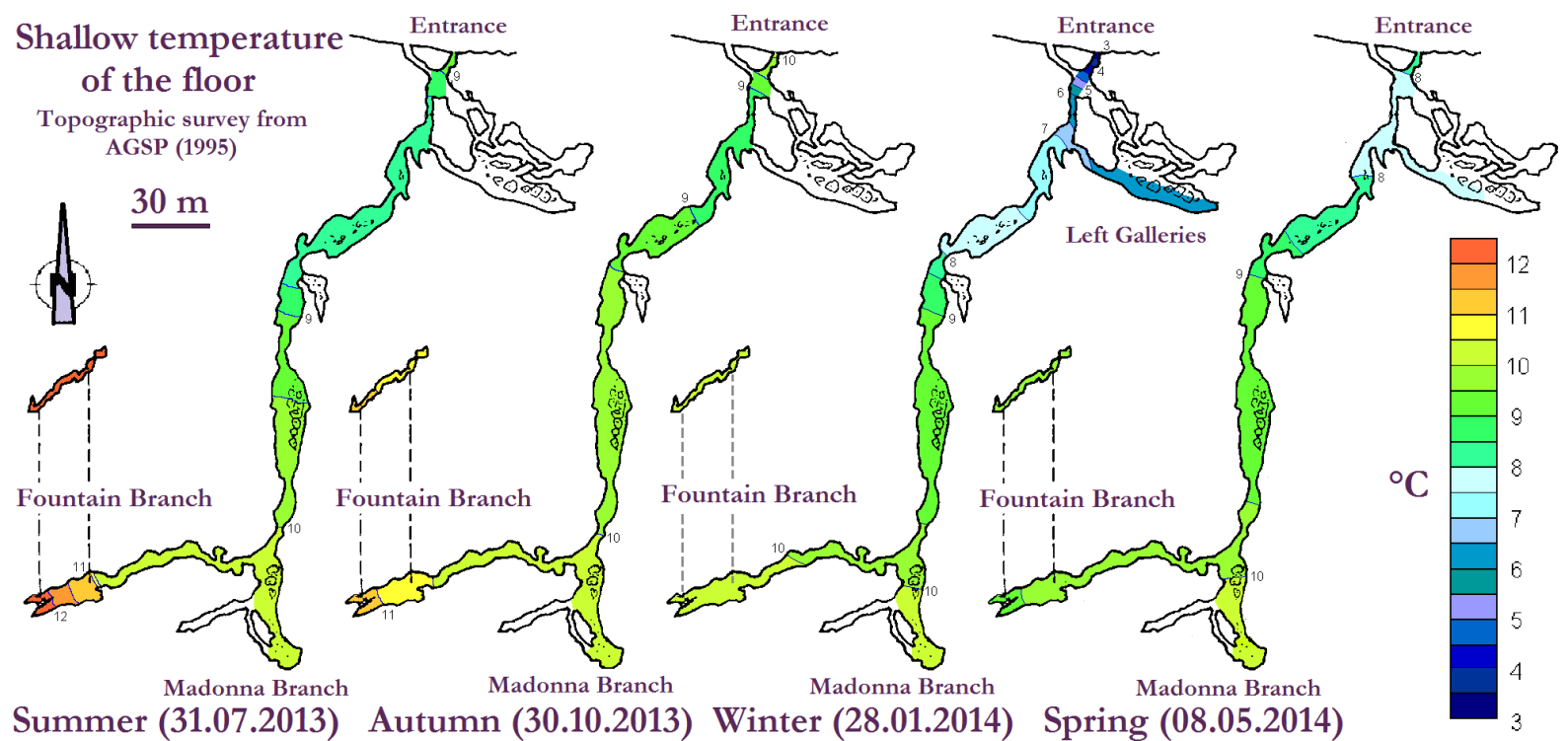

Figure 8. Seasonal distribution of temperature and humidity, inside Borna.

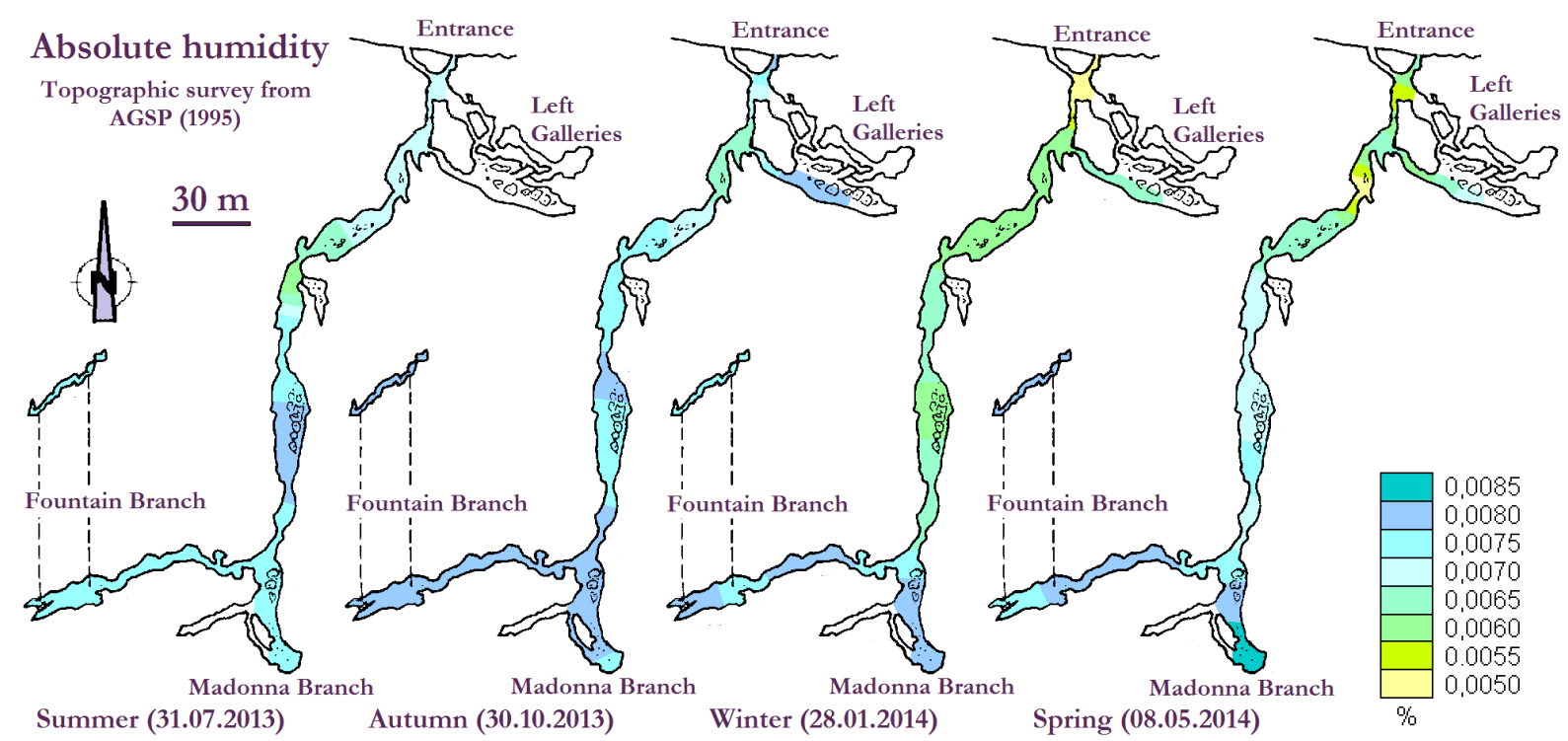

Figure 9. Map of absolute humidity ( $\mathrm{kg} / \mathrm{kg}$ ) calculated from distribution of temperature and relative humidity of Fig. 8. 


\section{Temperature distribution in the cross-sections}

The cross-sections of 8 May 2014 (Fig. 10) show small, but significant differences of air temperature $\left(0.2^{\circ} \mathrm{C}<\Delta \mathrm{T}^{\circ}<\right.$ $\left.1.1^{\circ} \mathrm{C}\right)$.

The thermic distribution in the entrance (section A) indicates a hot air flow at the time of the survey. The section at the level of the main floor has a homogeneous temperature area, surrounded by an area of strong temperature gradient: a true air current. A "cold hole" [2] is at the bottom left, where is one of the passages leading to the Left Galleries, with a temperature almost homogeneous of $6.6^{\circ} \mathrm{C}$.

In the sections $\mathrm{B}, \mathrm{C}$ and $\mathrm{D}$, all in narrows of the cave, the air is more and more hot towards the ceiling; it is still possible that a warm air current flows against the roof of the cavity. It isn't possible that the ceiling heat the air, because dripping water is colder than of air. In B and D, the soil seems to slightly heat the air.

The cross-sections of 15 January 2015 show the typical thermic distribution of the winter (Fig. 11).

The A section is not far from entrance (very close to A section in Fig. 10), in variable-temperature zone. The arrival of outer air makes cold the floor; but the ceiling stays warm, so the air is warmer than the air during the spring. In other words, this section explains the phase delay of annual thermic curve already mentioned.

The B section is in Main Branch (very close to B section in Fig. 10). Here, the air coming from outside (lower part of the section) is colder only of $0.5^{\circ} \mathrm{C}$. The temperature and moisture distribution on the ceiling surface shows that the water coming from the autogenic drainage heats the ceiling, maybe because this water warms up sinking in the path between the hill surface and the cave. The floor temperature is homogenous and it is mainly determined by the water temperature (also this water comes from autogenic drainage).

The $\mathrm{C}$ section is located in the Fountain Branch, at some meters from its beginning (close to D section in Fig. 10). The air is warmer than both ceiling and floor, but this is not due to a heat flow coming from water course at the end of the branch, because the temperature of this water course is in the same moment only of $8.3^{\circ} \mathrm{C}$.

The D section is in last chamber of the Madonna Branch. The water coming from the ceiling is slightly warmer (up to $11.2^{\circ} \mathrm{C}$ ) and makes the air temperatures quite homogenous $\left(10.5-11.0^{\circ} \mathrm{C}\right)$.

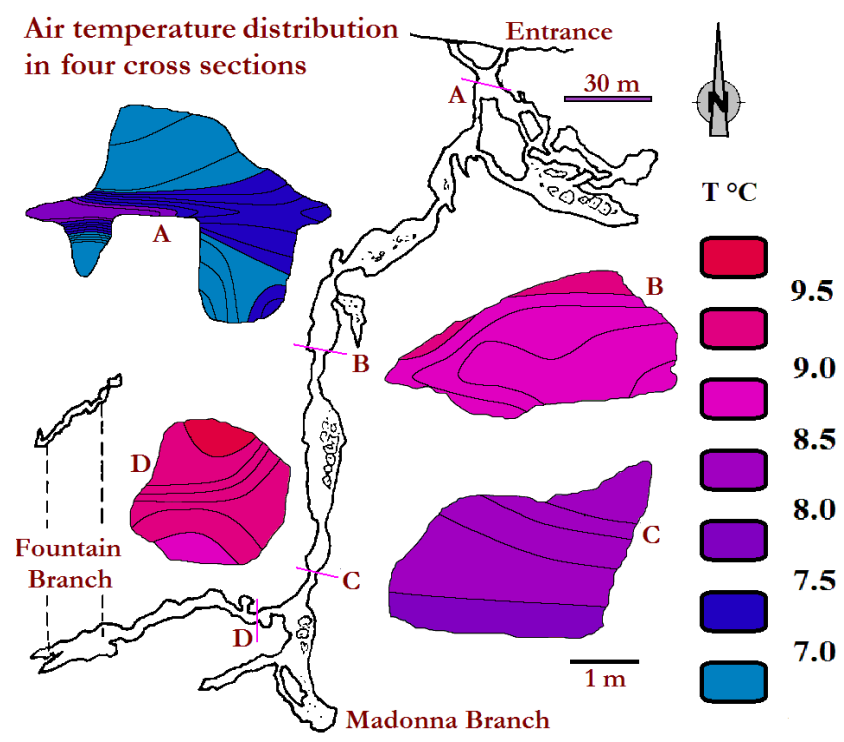

Figure 10. Air temperature in four cross sections (8 May 2014). The graphic scale of the map is at the top, the cross section scale is below it. Map of the cave re-drawed from [6].
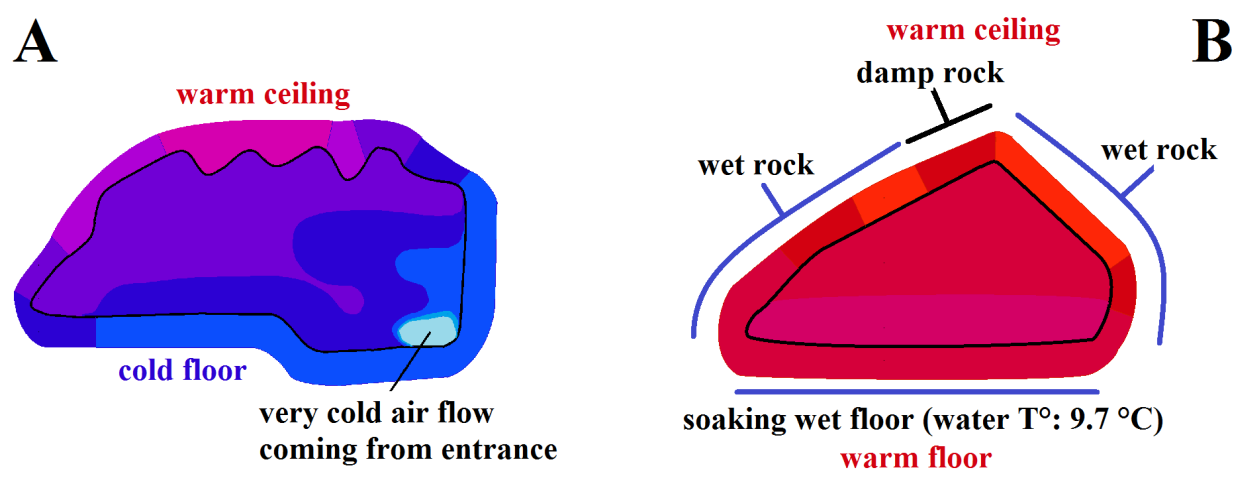

B

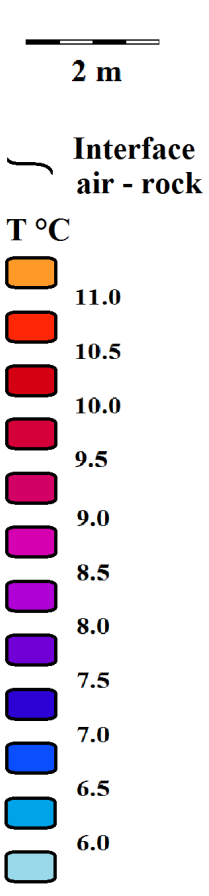

Figure 11. The cross sections of air temperatures, rock temperatures and moisture surveyed on $15^{\text {th }}$ of January 2015 . 


\section{Discussion on a hypothesis of thermic dynamics}

One possible explanation of the thermal oscillations inside the cave is that are linked directly to the outer atmosphere, even past the variable-temperature zone. In fact, the caves with more entrances in different conditions, have convection air flows, because "the mass of air inside the cave, for difference of density, tends to fall, and so comes out from lower openings during the summer, and draws the hot air from openings above the cave; for the same reason will tend to exit from the top during the winter, sucking cold air from lower entrances. The result is a temperature graph that follows a sinusoidal portion of outdoor temperatures during a season (summer for the upper entrance, winter for the lower entrance), and follows internal stabilized temperatures during other season" [15].

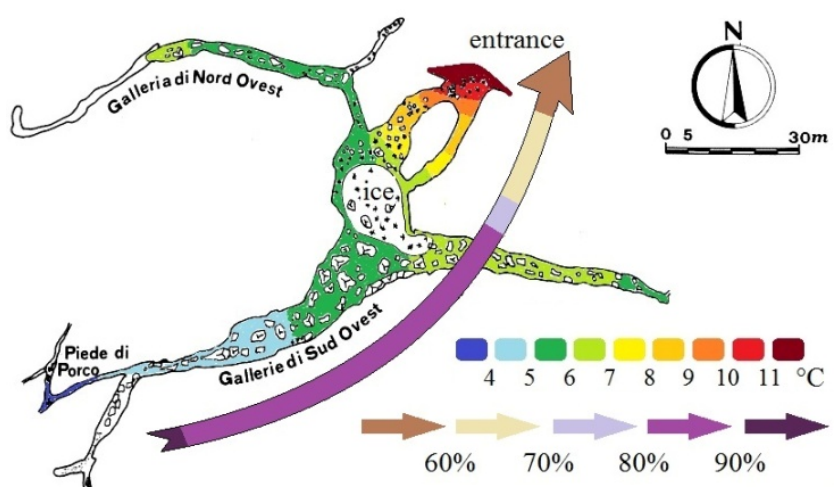

Figure 12. Temperature (map colors) and relative humidity (arrow colors) within a cave large like the Borna Maggiore, but with several entrances at different height (Grotta Ghiacciata del Mondolè, $102 \mathrm{Pi} / \mathrm{CN}$, [3]). During summer in the Gallerie di Sud Ovest a strong current flows. The air is less and less humid towards the main entrance. At the time of data collection the temperature range of the waters is $0^{\circ} \mathrm{C} \ldots+1.5^{\circ} \mathrm{C}$. Data collected by E.V. Motta, L. Motta, M. Motta in September 2002.

This phenomenon can happen at Pugnetto actually, only if this cave has at least a second entrance in different thermal conditions for altitude or exposure.

Based on current knowledge on the cave, the existence of unknown openings appears not likely. Moreover, in caves that have two entrances, like the Grotta Ghiacciata del Mondolè, the distribution of temperature and relative humidity is similar to that of Borna Maggiore (compare Fig. 8 with 12), but the gradients are big along the whole cave, so there is a strong air circulation [3].

\section{Conclusions}

The cave has (Fig. 13) a remarkable and never-ending thermal imbalance between Fountain Branch (warm) and entrance (cold). Therefore, the temperature oscillations of the outside air cannot be the only reason of the variations of the inner climate. The temperature distribution suggests three heat flows, all linked to the matter flows: the water stream of the Fountain Branch, the air entering from the entrance, the dripping water from the ceilings.

Two heat flows are acting always: the correspondents matter flows are the air currents, and the water stream of the Fountain Branch. The first is obviously very important near to the entrance (i.e., in the variable-temperature zone), and it acts as far as some 60 meters from the entrance. The second is important only in Fountain Branch: the evidence is its big seasonal variation of the temperature, compared with the closest galleries. In turn the temperature of the water flowing in Fountain Branch is following the average temperature of the aquifer recharge area. An important component of the thermal dynamics of Borna is therefore the thermal imbalance because of the change of exposure among Cenere Valley, where the infiltration area is a sunny and south-facing slope, and the shady entrance, in a north-facing slope.

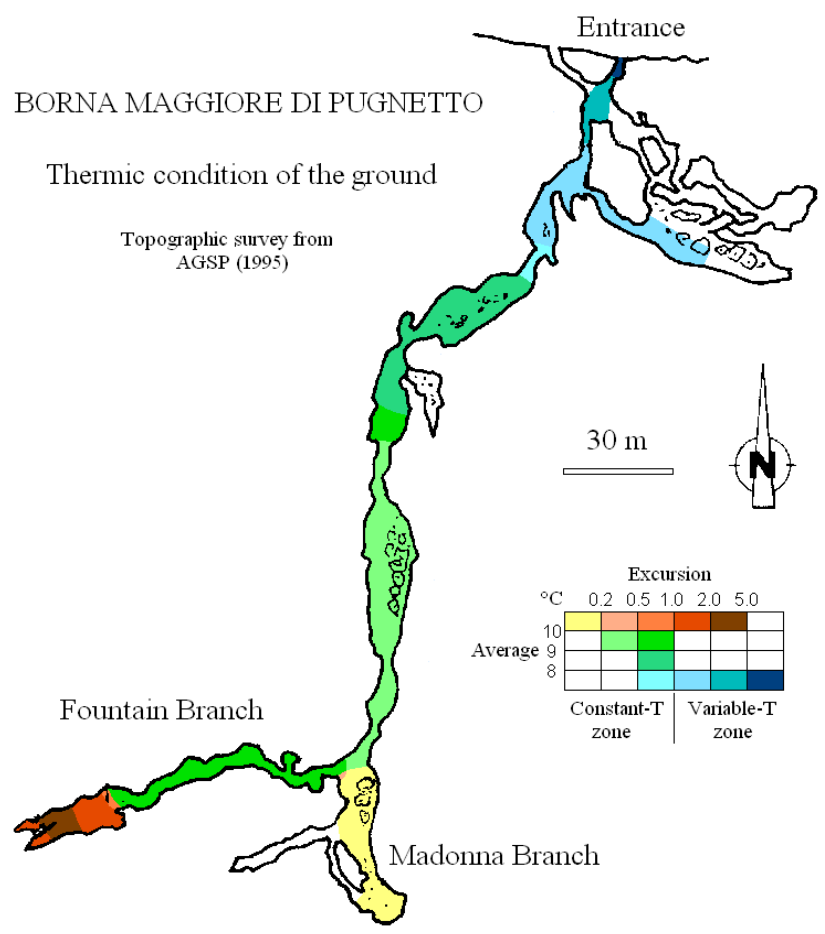

Figure 13. The Borna Maggiore has two variable-temperature zones, but with different features: near the entrance, the temperature average is the lowest of the cave; near the stream, the temperature average is the warmest. Also the constant-temperature zone has several sectors, with different temperature average: the Madonna Branch is warmer than Main Branch part of this zone.

It would be very interesting to know how varies the water temperature of the source respect to the temperature of the outdoor atmosphere. For further clarify this point, and both the influence of water temperature on the air and soil, in October 2014 we installed new synchronized stations that measure air, soil and water temperature.

The third heat flow, linked to the drip water, is important in the cave whole, but only during the period of bigger infiltration (starting from the periods of water surplus in the soil). This heat flow is the main reason of delay of thermic variations compared to the outside variations, and makes the cave climate very similar to a climate of a soil. Near to entrance, the thickness of rocks between cave ceiling and hill surface is little, so the infiltration water has a temperature 
close to that of air. In autumn, the water surplus of soil causes sudden increases of drip water in the cave after the rains, causing strong thermic oscillations of the inner climate.

Air traps, such as the Madonna Branch (warm air) or as the floor depressions in the Main Branch (cold air), have differentiated furtherly the microclimates.

In any case, a special feature of the Borna is that a variable-temperature zone, where air temperature fluctuates with the seasons, is located near the entrance, as well as at the end of the cave (Fountain Branch). This makes the Borna Maggiore like a cave open at the air circulation at both ends.

Probably the thermal dynamics of Borna Maggiore is present in all the numerous caves (e.g. resurgences like in Piedmont: Grotta delle Camoscere 105Pi/CN, Grotta W del Bandito $1003 \mathrm{Pi} / \mathrm{CN}$, Tana della Dronera $151 \mathrm{Pi} / \mathrm{CN}$...) with a entrance open to air circulation, while the bottom is open only to water (phreatic) circulation.

The Borna Maggiore is an environment thermally very stable as all karst systems, but with strong diversification in several thermal zones, both along the gallery axis, and in cross section. Similar conditions may favour the life of stenothermic arthropods. These animals in many parts of the cave can find a stable temperature all year round, and moving itself for a few decimetres they can exploit temperature differences between ground and air, finding exactly the optimum of temperature. On the contrary, probably eurythermic species prefer the variable-temperature zone near to the entrance.

The presence of some deep depressions of the floors, contributes to habitat heterogeneity within the cave. In fact, within these depressions the air is motionless, and thus it tends to become cold at the bottom (Fig. 10, A section). This creates a suitable habitat for cryophilic species, which can take advantage of these "cold holes". On the contrary the bats during the winter can take advantage of the warm air that is near to ceiling. Also the relative humidity being variable, and so the animals can find relatively saturated or dry environments. This variability in term of micro-habitats, together at the proximity to glacier in past, is probably the cause that determines the peculiar biodiversity that we can observe in the Pugnetto site.

\section{Acknowledgements}

This study is part of the CaveLab project "From microclimate to climate change: caves as a laboratory for the study of the effects of temperature on ecosystems and biodiversity", funded by the University of Turin and Compagnia di San Paolo (Progetti di Ateneo 2011 ORTO11T92F).

Also the University of Turin project "Contrasti termici e umidità in microclimi di grotte di particolare interesse naturalistico" (MOTMRIL013) has funded partially this study.

The Piedmont Region in agreement with University of
Turin (co-coordinator Michele Motta) has funded the census of erratic blocks for implementing the Regional Law n. 23 of 21.10.2010 "Development and preservation of erratic blocks that have high landscape, environment and history value".

We thank Paolo Debernardi (Stazione Teriologica Piemontese), Enrico Valerio Motta (Geokalé), Giorgio Perron Cabus, Gino Cena (CAI) to the kind collaboration in data collection phase. We would like to thank also the colleagues of CaveLab for the placement of the Hygrochron, the fruitful exchange of information and continuous cooperation, and in particular Marco Isaia, Stefano Mammola and Elena Piano that have recovered the I-buttons and have contributed with useful discussions at this paper, Giovanni Badino and Dario Melacarne that have contributed to the analysis of I-buttons data.

\section{REFERENCES}

[1] C. Arnò, E. Lana, Ragni cavernicoli del Piemonte e della Valle d'Aosta. Regione Piemonte \& Associazione Gruppi Speleologici Piemontesi, Torino, 2005.

[2] G. Badino, Fisica del clima sotterraneo, Memorie dell'Istituto Italiano di Speleologia, Bologna, 1995.

[3] C. Balbiano d'Aramengo, AGSP, Le grotte del Piemonte. Guida per l'escursionismo, Via dalla Pazza Folla Ed., Cassolnovo, Pavia, 1993.

[4] L. Botosaneanu, J.R. Holfinger, Some aspects concerning colonization of the subterranean realm-especially of subterranean waters: a response to Rouch \& Danielopol, 1987. Stygologia, Vol.6, 129-142, 1991.

[5] C. F. Capello, Il fenomeno carsico in Piemonte. Le zone interne al sistema alpino, C.N.R. Centro studi geografia fisica, Ser. 10, Vol. 6., Mareggiani, Bologna, 1955.

[6] A. Eusebio (Ed.), Atlante delle grotte e delle aree carsiche piemontesi, Regione Piemonte \& AGSP, Torino, 1995.

[7] P. M. Giachino, D. Vailati, The subterranean environment. Hypogean life, concepts and collecting techniques, WBA Handbooks, Verona, 2010.

[8] M. Isaia, P. Pantini, A new species of Troglohyphantes (Araneae, Linyphiidae) from the Western Italian Alps, The Journal of Arachnology, Vol.35, 427-431, 2008.

[9] M. Isaia, M. Paschetta, E. Lana, P. Pantini, A.L. Schonhofer, E. Christian, G. Badino, Subterranean Arachnids of the Western Italian Alps (Arachnida: Araneae, Opiliones, Palpigradi, Pseudoscorpiones), Monografie XLVII, Museo Regionale di Scienze Naturali, Torino, 2011.

[10] M. Isaia, M. Paschetta, A. Chiarle, G. Badino, S. Berto, F. Bona, M. Meregalli, M. Motta, L. Motta, D. Vione, A. Vizzini, CAVELAB, an interdisciplinary research project for the study of cave ecosystems and their potentialities for the study of global change, Abstract Book of XIX International Congress of Arachnology, Kenting, Taiwan, 23-28 June 2013, Thungai University, 201-202, 2013.

[11] C. Juberthie, B. Delay, M. Bouillon, Extension du milieu souterrain en zone non-calcaire: description d'un nouveau 
milieu et de son peuplement par les coléoptères troglobies, Mémoires Biospéologiques, Vol.7, 19-52, 1980.

[12] C. Juberthie, B. Delay, M. Bouillon, Sur l'existence du milieu souterrain superficiel en zone calcaire, Mémoires Biospéologiques, Vol.8, 77-93, 1981.

[13] E. Lana, Biospeleologia del Piemonte, Regione Piemonte \& AGSP, Torino, 2001.

[14] C. Lanza, Aspetti antropici delle grotte del Piemonte, Rassegna Speleologica Italiana, Vol.18, No.3-4, 1-19, 1966.

[15] D. Melacarne, L'influenza del clima e della meteorologia esterna sugli ambienti sotterranei. Thesis, Natural Sciences, University of Torino, A.A. 2012-2013, unpublished.

[16] L. Motta, M. Motta, The protection Law and the Register of erratic Blocks in Piedmont (Italy), as Example of Protection of a widespread Geosite in a densely populated Region, Advanced Research in Scientific Areas 2012, Section 10 Natural Sciences, EDIS, Zilina, Slovak Republic, 1534-1539.

[17] L. Motta, M. Motta, Massi erratici, Regione Piemonte, Torino, 2013.

[18] L. Motta, M. Motta, Oscillations of temperatures in Piedmont caves remarkable for speleofauna, SCIECONF 2014, EDIS, Zilina, Slovak Republic, 412-417.

[19] M. Motta, The Definition of the Extension of Quaternary Glaciers within Alpine Valleys, and his Application to Study of Subterranean Fauna, QUAESTI 2014, EDIS, Zilina,
Slovak Republic, 439-444.

[20] G. Muratore, Grotte del Pugnetto, Rivista mensile Club Alpino Italiano, Vol.44, No.8, 192-197, 1925.

[21] G. Muratore, Grotte del Pugnetto, valli di Lanzo - Stura di Ala, Rivista mensile Club Alpino Italiano, Vol.65, No.1-2, 21-29, 1946.

[22] L. Ramella, Italie, in: C. Chabert, P. Courbon (eds.), Atlas des cavités non calcaires du monde, Union Intérnational de Spéléologie, 68-70, 1997.

[23] F. Sacco, Caverne delle Alpi Piemontesi, Le grotte d'Italia, Vol.2, No.3, 97-121, 1928.

[24] R. Sindaco, P. Savoldelli A. Selvaggi, La Rete Natura 2000 in Piemonte. I Siti di Importanza Comunitaria, Regione Piemonte, Torino, 2008.

[25] B. Vigna, Il carsismo piemontese, in: A. Eusebio, B. Vigna (eds.), Sintesi delle conoscenze sulle aree carsiche piemontesi, AGSP, Torino, 11-16, 1986.

[26] A. Vigna Taglianti, Considerazioni sulla coleotterofauna cavernicola del Piemonte, Archivio botanico e biogeografico italiano, Vol.44, No.4, 252-264, 1968.

[27] Online available from http://webgis.arpa.piemonte.it/ geoportale/

[28] Online available from http:// www.speleo-doubs.com/congres2014 